Bioscientia Medicina: Journal of Biomedicine \& Translational Research

Journal Homepage: www.bioscmed.com

\title{
Relationship Between Vitamin D Supplementation and Improvement in Body for Carcinogenesis: A Literature Review
}

\author{
Irawan Sastradinata ${ }^{{ }^{*}}$, Rizal Sanif ${ }^{1}$, Cindy Kesty ${ }^{2}$, Siti Hardianti Harahap ${ }^{2}$
}

${ }^{1}$ Division of Oncology Gynecology, Department of Obstetry and Gynecology, Faculty of Medicine, Universitas Sriwijaya/ Dr. Mohammad Hoesin General Hospital, Palembang, Indonesia

2 Department of Obstetry and Gynecology, Faculty of Medicine, Universitas Sriwijaya/ Dr. Mohammad Hoesin General Hospital, Palembang, Indonesia

\section{A R T I C L E I N F O \\ Keywords: \\ Alternative medicine \\ Carcinogenesis \\ Vitamin D \\ *Corresponding author: \\ Irawan Sastradinata \\ E-mail address: \\ irawansastradinata@fk.unsri.ac.id}

All authors have reviewed and approved the final version of the manuscript.

https://doi.org/10.37275/bsm.v6i2.447

\begin{abstract}
A B S T R A C T
Vitamins are probably the best-selling dietary supplements in the United States, in which an estimated $35 \%$ of the population take multivitamin and mineral supplements. Data relating microconstituents to carcinogenesis are extremely limited, as explained in the first report. A striking feature of many of the compounds in the three groups mentioned above is their capacity to prevent or retard the occurrence of neoplasia. However, there is a paucity of data concerning the conditions under which inhibition occurs, the mechanisms of inhibition, and the precise impact of these microconstituents on humans. A literature review was conducted in the electronic databases PubMed and Google Scholar using the index terms "carcinogenesis" and "cancer" and "vitamin D" All types of studies were included for this study, such as randomized controlled trials, systematic reviews, literature reviews, and pilot studies published between 2010 and 2021. Articles which not written in English were excluded from the study. This search resulted in 10 papers. Many of the mechanisms proposed for vitamin D and cancer prevention have been studied only in the context of one tissue or one type of cancer and so further studies must be conducted to determine if these mechanisms can be generalized. For example, while higher serum $(25(\mathrm{OH}) \mathrm{D} 3)$ is associated with reduced cancer risk, and CYP27B1 is expressed in nonrenal cells, there is no evidence that the low-level expression of CYP27B1 in tissues leads to meaningful local production of $1 \mathrm{a}, 25(\mathrm{OH}) 2 \mathrm{D} 3$ or calcitriol, and that this mediates the protection from cancer provided by high vitamin D status. In conclusion, we suggest that vitamin D compounds to be employed in the treatment of, alone or in combination with other anticancer agents. solar UV-B radiation, acting through the production of vitamin $\mathrm{D}$, is a risk reduction factor for over a dozen forms of cancer.
\end{abstract}

\section{Introduction}

Cancer is a major cause of debilitation and death in humans and animals. Cancer develops as a function of age, environment, diet, and genetic makeup, whether in man or animals. As humans reach their sixth decade, they face an exponentially increased risk for developing cancer. There is a similar window of increased susceptibility to chemically-induced neoplasms in rodents treated with either a single or chronic exposure(s) to carcinogen(s). Identifying potential human carcinogens in rodent bioassays has been a major focus of the field of toxicologic pathology. It is estimated that $5 \%$ of human cancers are caused by viruses, $5 \%$ by radiation, and the remaining $90 \%$ by chemicals. Of these, an estimated $30 \%$ are caused by the use of tobacco products and the rest by chemicals associated with diet, lifestyle, and the environment. ${ }^{1}$

Most humans obtain their vitamin D requirement from exposure to sunlight. Ultraviolet light is present in sunlight and is essential for the production of vitamin $\mathrm{D}$, a fat-soluble vitamin essential for proper absorption and retention of calcium and phosphorus, which are the building blocks of bone. Vitamin D deficiency may lead to increased risk of fractures and may also cause rickets. Adequate exposure to sunlight is the best way 
to prevent vitamin D deficiency. Human skin is capable of producing enough vitamin $\mathrm{D}$ from dehydrocholesterol when exposed to the ultraviolet light of the sun, which is then stored in body fat. Estimates of betouren $80 \%$ and $100 \%$ of the vitamin D needed by humans come from exposure to sunlight. Vitamin D is a fat-soluble vitamin that exists in two forms: vitamin D2 (ergocalciferol) and vitamin D3 (cholecalciferol). Dietary consumption of UVB-exposed plants and fungi is the primary source of vitamin D2 in humans. Vitamin D3 can also be obtained through diet, mostly from oily fish. However, over 90\% of the body's daily vitamin $\mathrm{D}$ requirements are produced in the skin upon exposure to sunlight. After consumption or synthesis of vitamin D, both forms It is well established that when vitamin D3 is made in the skin and vitamin D2 and vitamin D3 are ingested from the diet, they enter the liver, where they are converted to 25hydroxyvitamin D2 and 25-hydroxyvitamin D3 [25(OH)D; D without subscript represents either $\mathrm{D}_{2}$ or $\mathrm{D}_{3}$ ]. $25(\mathrm{OH}) \mathrm{D}$ is the major circulating form of vitamin $\mathrm{D}$ that is used to determine the vitamin D status of an individual. ${ }^{2-4}$

Vitamin D is biologically inert and when ingested in the diet or made in the skin travels to the liver on the vitamin D-binding protein, where it is converted to 25hydroxyvitamin $\mathrm{D}[25(\mathrm{OH}) \mathrm{D}] .25(\mathrm{OH}) \mathrm{D}$ is the major circulating form of vitamin D and is most useful to determine the vitamin D status of animals and human. However, it is biologically inert at physiological concentrations. It requires further metabolism in the kidney by the mitochondrial 25-hydroxyvitamin D-1ahydroxylase (1OHase). The resulting product, 1,25dihydroxyvitamin $\mathrm{D}_{3}(1,25(\mathrm{OH}) 2 \mathrm{D})$, is responsible for carrying out all of the calcium metabolism functions of vitamin $\mathrm{D}$, i.e., maintaining the serum calcium and phosphate level in the normal range. This is accomplished by $1,25(\mathrm{OH})_{2} \mathrm{D}$ interacting with its specific nuclear vitamin D receptor (VDR) in the small intestine. $1,25(\mathrm{OH})_{2} \mathrm{D}$ increases the efficiency of intestinal calcium absorption and phosphate absorption.

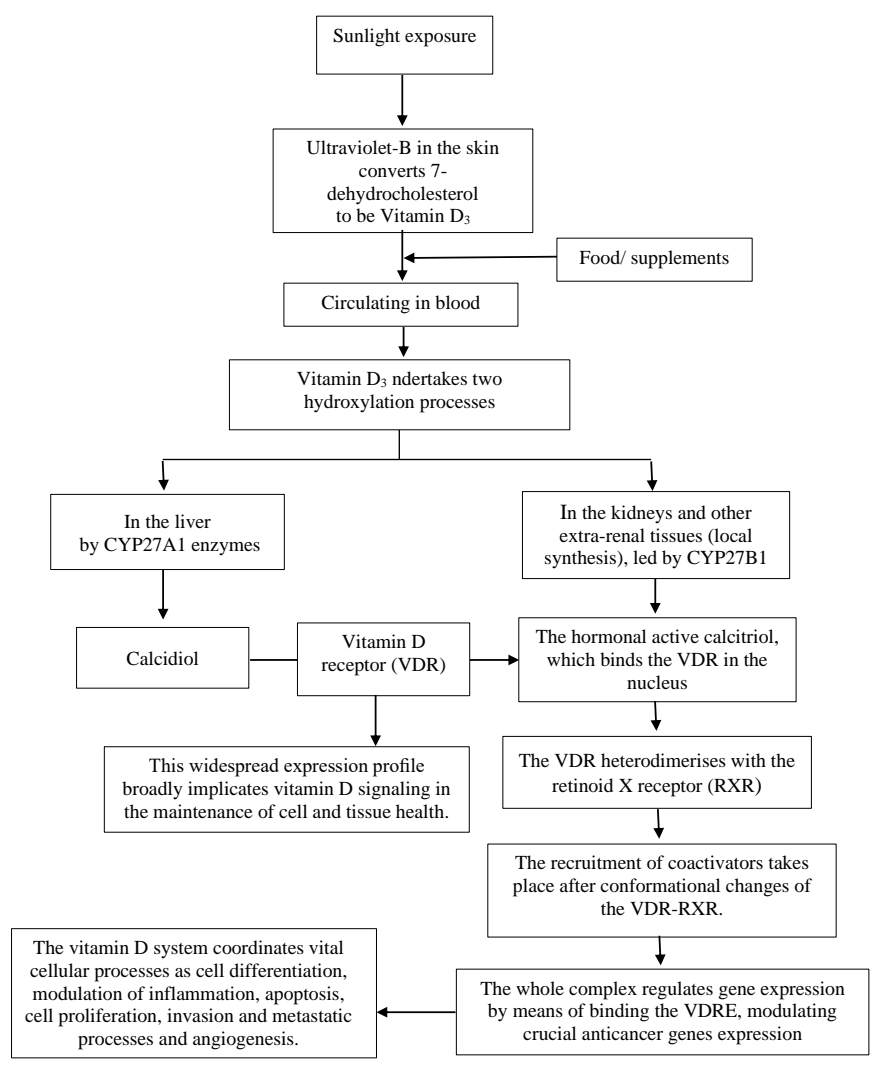

Figure 1: VDR affects approximately 3\% of the human genome, influencing more than 750 genes. Moreover, VDR expression in humans is found in at least 38 cell lineages. The variety of cells ranges from B lymphocytes, monocytes, macrophages, to colon cancer and hepatic stellate cells. Such width and pleiotropic action can give us a clue to the importance of proper VDR signalling and regulation in maintaining health and preventing disease. ${ }^{5}$ 


\section{Methods}

The researcher searched for all studies published between 03 January 2019 and 03 November 2021, using Google Scholar and PubMed. The following keywords were applied during the literature search: "Vitamin D" AND "Cancer," "Carcinogenesis" AND "Vitamin D". The researcher added additional studies through a manual search, which is relevant to this review. The inclusion criteria were studies that describe the effect of vitamin D supplementation. The exclusion criteria were studies that include other conditions (Adequate data on the association between vitamin $\mathrm{D}$ supplementation and mortality, were not independent, or in which data on cancer mortality were missing), parathyroid disease, those with chronic renal failure, and those with calcium-phosphate, metabolism disorder, renal failure or dialysis, cirrhosisand history of hypercalcemia.

Moreover, because these confounding factors are difficult to account for this study, the adjusted results were used and discussed in this article when available. In the first step, the researcher assesses the titles and abstracts of the studies to exclude reports based on the criteria. In the second step, the researcher read and evaluated the full-text studies that met the requirements.

\section{Results}

The PubMed, nutrients and google scholar search results identified 220 potential studies, with 203 remaining studies after removing duplicates. After reviewing the titles and abstracts from 203 studies, 17 studies were identified for possible inclusion in the review. After examining the full text of the 17 studies against the inclusion criteria, nine studies were excluded. Reasons for exclusion were: studies that include other conditions (Adequate data on the association between vitamin $\mathrm{D}$ supplementation and mortality, were not independent, or in which data on cancer mortality were missing), parathyroid disease, those with chronic renal failure, and those with calcium-phosphate, metabolism disorder, renal failure or dialysis, cirrhosisand history of hypercalcemia. See Figure 1 for the process of search results. The 10 selected studies were consisted of 2 Cohort studies, 1 stratified multi-cluster random sampling method, 5 randomized controlled clinical trial, 1 Cross-sectional study and 1 Retrospective study conducted in different countries such as Indonesia, China, Turkey, Germany, USA and Iran.

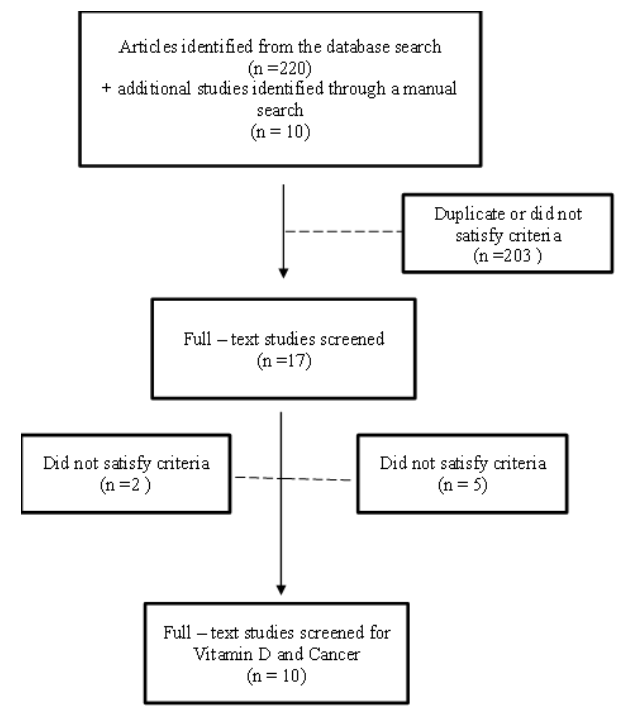

Figure 2: The process of search results

Participants in each study were varied, wherein Five RCTs the number of participants ranged from 1200 to 26000 and the distribution of male and female participants in 5 RCTs are similar which not only male but also female participants. ${ }^{6-12}$ Two Cohort studies with one study had among the 94,205 women studied and documented 111 and another one 2509 cases (1494 men and 1015 women) incident cases of early- 
onset. ${ }^{10}$ A stratified multi-cluster random sampling method 1806 rural subjects (35\% males and $65 \%$ females). ${ }^{11,13} \mathrm{~A}$ Cross-sectional study had 20 cervical cancer patients based on clinical and histopathological results and 20 women without cervical cancer based on clinical and pap smear results. ${ }^{9} \mathrm{~A}$ retrospective study had 355 patients were examined (157 oncologic patient group and 198 in the control group). ${ }^{14-18}$
Nine from ten studies had resulted there is beneficial effect of vitamin D supplement on lowering cancer mortality9,10,11,12,13,15,6,17,18 and One randomized, placebo-controlled trial study, resulted no significant differences between the two groups were observed with regard to the incidence of breast, prostate, or colorectal cancer. ${ }^{14}$

Table 1. Summary of studies.

\begin{tabular}{|c|c|c|c|c|}
\hline Article & Ref. & Design Study & Sample & Main Results \\
\hline $\begin{array}{l}\text { Associations of vitamin D } \\
\text { status with colorectal } \\
\text { cancer risk and survival }\end{array}$ & $\begin{array}{l}\text { Zhou, Jian } \\
\text { et al }\end{array}$ & $\begin{array}{l}\text { A Prospective } \\
\text { cohort study }\end{array}$ & $\begin{array}{l}\text { Total of } 2509 \text { CRC cases } \\
\text { (1494 men and } 1015 \\
\text { women) }\end{array}$ & $\begin{array}{l}\text { Indicates that higher levels of prediagnostic } 25(\mathrm{OH}) \mathrm{D} \text { were } \\
\text { associated with lower risk and improved survival of CRC. Large- } \\
\text { scale and long-duration RCTs are needed to assess whether } \\
\text { elevating } 25(\mathrm{OH}) \mathrm{D} \text { concentration in persons with vitamin D } \\
\text { deficiency and insufficiency is effective in reducing CRC } \\
\text { incidence and mortality. }\end{array}$ \\
\hline $\begin{array}{l}\text { Prevalence of vitamin D } \\
\text { deficiency and its associated } \\
\text { risk factors among rural } \\
\text { population of the northern } \\
\text { part of the Persian Gulf }\end{array}$ & $\begin{array}{l}\text { Marzban, } \\
\text { et al }\end{array}$ & $\begin{array}{l}\text { A stratified multi- } \\
\text { cluster random } \\
\text { sampling method. }\end{array}$ & $\begin{array}{l}1806 \text { rural subjects }(35 \% \\
\text { males and } 65 \% \text { females })\end{array}$ & $\begin{array}{l}\text { The prevalence of vitamin D deficiency was high among its rural } \\
\text { population. The shift of their lifestyle patterns and rapid } \\
\text { industrialization in these rural areas may be responsible. } \\
\text { Therefore, the enrichment of dietary sources with vitamin D and } \\
\text { the use of vitamin D supplements are recommended to tackle the } \\
\text { high prevalence of vitamin D deficiency in the rural population of } \\
\text { the northern part of the Persian Gulf. }\end{array}$ \\
\hline $\begin{array}{l}\text { Total Vitamin D Intake and } \\
\text { Risks of } \begin{array}{l}\text { Early-Onset } \\
\text { Colorectal } \\
\text { Precursors }\end{array}\end{array}$ & $\begin{array}{l}\text { Hnaseul, } \\
\text { et al }\end{array}$ & A Cohort study & $\begin{array}{l}\text { Among the } 94,205 \text { women } \\
\text { studied, we documented } \\
111 \text { incident cases of early- } \\
\text { onset CRC. }\end{array}$ & $\begin{array}{l}\text { The research found evidence that higher total vitamin D intake is } \\
\text { associated with decreased risks of early onset } \\
\text { CRC and precursors. This results further support that avoiding low } \\
\text { vitamin D status is important in younger adults for health and } \\
\text { possibly CRC prevention. If confirmed, findings could potentially } \\
\text { lead to recommendations for higher vitamin D intake as an } \\
\text { inexpensive low-risk complement to CRC screening as CRC } \\
\text { prevention strategy for } \\
\text { adults younger than age } 50\end{array}$ \\
\hline $\begin{array}{l}\text { Vitamin D Supplements and } \\
\text { Prevention of Cancer and } \\
\text { Cardiovascular Disease }\end{array}$ & $\begin{array}{l}\text { Manson et } \\
\text { al }\end{array}$ & $\begin{array}{l}\text { A randomized, } \\
\text { placebo-controlled } \\
\text { trial, with a two-by- } \\
\text { two factorial design }\end{array}$ & $\begin{array}{l}\text { A total of } \begin{array}{r}25,871 \\
\text { participants, } \\
\text { including }\end{array} \\
\begin{array}{l}\text { and cancer was black } \\
\text { diagnosed in } \\
\text { participant }\end{array}\end{array}$ & $\begin{array}{l}\text { The primary end point of invasive cancer of any type developed in } \\
1617 \text { participants, with similar event rates in the vitamin D group } \\
\text { and the placebo group ( } 793 \text { and } 824 \text { participants with cancer, } \\
\text { respectively; hazard ratio, } 0.96 ; 95 \% \text { confidence interval }[\mathrm{CI}], 0.88 \\
\text { to } 1.06 ; \mathrm{P}=0.47 \text { ) (Table } 2 \text { ). No significant differences between the } \\
\text { two groups were observed with regard to the incidence of breast, } \\
\text { prostate, or colorectal cancer. During follow-up, } 341 \text { participants } \\
\text { died from cancer, with } 154 \text { such deaths in the vitamin D group and } \\
187 \text { in the placebo group (hazard ratio, } 0.83 ; 95 \% \mathrm{CI}, 0.67 \text { to } 1.02 \text { ). }\end{array}$ \\
\hline $\begin{array}{l}\text { Meta-analysis of } \\
\text { randomized controlled trials } \\
\text { on vitamin D supplement } \\
\text { and cancer incidence and } \\
\text { mortality }\end{array}$ & Zang et al & $\begin{array}{l}\text { A randomized } \\
\text { controlled clinical } \\
\text { trial }\end{array}$ & 81362 participants. & $\begin{array}{l}\text { There is support a beneficial effect of vitamin D supplement on } \\
\text { lowering cancer mortality, especially in subpopulations with no } \\
\text { history of cancer, extra use of vitamin } \mathrm{D} \text {, or calcium supplement }\end{array}$ \\
\hline $\begin{array}{l}\text { Vitamin D supplementation } \\
\text { to the older adult population } \\
\text { in Germany has the cost- } \\
\text { saving potential of } \\
\text { preventing almost } 30 \text { o00 } \\
\text { cancer deaths per year }\end{array}$ & $\begin{array}{l}\text { Niedermaie } \\
\mathrm{r} \text { et al } 1\end{array}$ & $\begin{array}{l}\text { A randomized } \\
\text { controlled clinical } \\
\text { trial }\end{array}$ & $\begin{array}{l}\text { The number of deaths } \\
\text { and years of life lost (YLL) } \\
\text { due to cancer in Germany } \\
\text { is estimated }\end{array}$ & $\begin{array}{l}\text { It might be an extremely effective and economic approach to limit } \\
\text { the burden of cancer in addition to its well-established or most } \\
\text { likely beneficial effects on bone health and other major health } \\
\text { outcomes. }\end{array}$ \\
\hline $\begin{array}{l}\text { Effect of Vitamin D3 } \\
\text { Supplements on Development } \\
\text { of Advanced Cancer } \\
\text { A Secondary Analysis of the } \\
\text { VITAL Randomized Clinical } \\
\text { Trial }\end{array}$ & $\begin{array}{l}\text { Chandler } \\
\text { et }\end{array}$ & $\begin{array}{l}\text { A randomized } \\
\text { controlled clinical } \\
\text { trial }\end{array}$ & 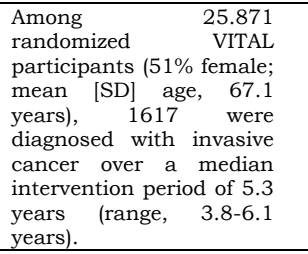 & $\begin{array}{l}\text { When stratified by BMI, there was a significant reduction for the } \\
\text { vitamin D arm in incident metastatic or fatal cancer among those } \\
\text { with normal BMI (BMI<25: HR, 0.62 [95\% CI, 0.45-0.86]) but not } \\
\text { among those with overweight or obesity (BMI 25-<30: HR, } 0.89 \\
\text { [95\% CI, 0.68-1.17]; BMI_30: HR, } 1.05 \text { [95\% CI, 0.74-1.49]) }(\mathrm{P}= \\
.03 \text { for interaction by BMI). In this randomized clinical trial, } \\
\text { supplementation with vitamin D reduced the incidence of } \\
\text { advanced (metastatic or fatal) cancer in the overall cohort, with } \\
\text { the strongest risk reduction seen in individuals with normal } \\
\text { weight. }\end{array}$ \\
\hline $\begin{array}{l}\text { Comparison of VDR } \\
\text { Expression and Blood Vitamin } \\
\text { D } 1.25(\mathrm{OH}) 2 \\
\text { Level between Cervical } \\
\text { Cancer Patients and Normal } \\
\text { Women }\end{array}$ & $\begin{array}{l}\text { Askandar, } \\
\text { et al }\end{array}$ & $\begin{array}{l}\text { A Cross-sectional } \\
\text { study. }\end{array}$ & $\begin{array}{l}20 \text { cervical cancer patients } \\
\text { based on } \\
\text { clinical and } \\
\text { histopathological results } \\
\text { and } 20 \text { women without } \\
\text { cervical cancer based on } \\
\text { clinical and pap smear } \\
\text { results }\end{array}$ & $\begin{array}{l}\text { Indicated a higher expression of VDR and lower levels of vitamin } \\
\text { D } 1.25(\mathrm{OH}) 2 \text { in cervical cancer compared to normal women. Low } \\
\text { levels of vitamin D increase the risk of cervical cancer incidence } \\
\text { by } 2.7 \text { times greater, and higher VDR expression increases the } \\
\text { risk of cervical cancer incidence } 2 \text { times greater. }\end{array}$ \\
\hline $\begin{array}{l}\text { Comparison of Vitamin D } \\
\text { Levels Between Healthy } \\
\text { Individuals and Cancer } \\
\text { Patients }\end{array}$ & $\begin{array}{l}\text { Aytekin, } \\
\text { Aydin }\end{array}$ & $\begin{array}{l}\text { A Retrospective } \\
\text { study }\end{array}$ & $\begin{array}{l}355 \text { patients were } \\
\text { examined (157 oncologic } \\
\text { patient group and } 198 \text { in } \\
\text { the control group) }\end{array}$ & $\begin{array}{l}\text { vitamin D deficiency was found to be very common in cancer } \\
\text { patients }(87.3 \% \text { according to reference value of } 20 \mathrm{ng} / \mathrm{mL}) \text { and } \\
\text { vitamin D levels were lower in cancer patients compared to the } \\
\text { control group. } 10 \mathrm{ng} / \mathrm{mL} \text { is a suitable reference value for defining } \\
\text { vitamin D deficiency in cancer patients }\end{array}$ \\
\hline $\begin{array}{l}\text { Prevention of Advanced } \\
\text { Cancer by Vitamin D3 } \\
\text { Supplementation: } \\
\text { Interaction by Body Mass } \\
\text { Index Revisited }\end{array}$ & $\begin{array}{l}\text { Brenner et } \\
\text { al }\end{array}$ & $\begin{array}{l}\text { A randomized } \\
\text { controlled clinical } \\
\text { trial }\end{array}$ & $\begin{array}{l}25,871 \text { for women an } \\
\text { men, protective effects of } \\
\text { vitamin D3 } \\
\text { supplementation (2000 } \\
\text { IU/day over a median of } \\
5.3 \text { years) with respect to } \\
\text { incidence of any cancer } \\
\text { and of advanced cancer } \\
\text { were seen for normal } \\
\text { weight participants }\end{array}$ & $\begin{array}{l}\text { The observed patterns point to pre-diagnostic weight loss of } \\
\text { cancer patients and preventive effects of vitamin D3 } \\
\text { supplementation from cancer progression as plausible } \\
\text { explanations for the body mass index (BMI)-intervention } \\
\text { interactions. Further research, including RCTs more } \\
\text { comprehensively exploring the potential of adjuvant vitamin D } \\
\text { therapy for cancer patients, should be pursued with priority. }\end{array}$ \\
\hline
\end{tabular}




\section{Discussion}

The worldwide increase in life expectancy raises the rates of cancer morbidity and mortality, with some 18 million new cancer cases and nearly 10 million cancer deaths in 2018. The costly treatment of the disease, such as surgery, radiation therapy and chemotherapy, is a financial burden for the healthcare systems of developed countries and is even not easily accessible to the majority of the population in developing countries. Thus, there is urgent need for anti-cancer options that combine preventive with therapeutic potentials, ideally at low cost. In this context vitamin D3 (also called cholecalciferol) has gained significant attention as an inexpensive and readily accessible natural compound. The main source of this seco-steroid is its non-enzymatic production in human skin from UV-B exposed 7dehydrocholesterol, which is an abundant direct cholesterol precursor.2,3,6

Vitamin $\mathrm{D}$ is a fat-soluble vitamin that can be synthe- sized in the skin through energy of sunlight or can be obtained from the diet or supplements. The $25(\mathrm{OH}) \mathrm{D}$ - the major circulating form of vitamin $\mathrm{D}$ - is a pre-hormone that is produced in the liver by hydroxylation of both isoforms, which in turn, comes from diet, supplements, or its production by the skin. In clinical practice, the measurement of $25(\mathrm{OH}) \mathrm{D}$ as a blood test is considered the best indicator of vitamin D status for different outcomes, including the risk of cancer. However, the active form for vitamin $\mathrm{D}$ is 1,25(OH)2D3 (calcitriol). Although there are some discrepancies on adequate serum levels of vitamin D for health outcomes, a recent study indicates that the recommended serum $25(\mathrm{OH}) \mathrm{D}$ for the prevention of CRC must exceed $30 \mathrm{ng} / \mathrm{mL}$, and the best values were situated at levels between 3 and $40 \mathrm{ng} / \mathrm{mL}^{3,7}$

Early epidemiologic research showed that incidence and death rates for certain cancers were lower among individuals living in southern latitudes, where levels of sunlight exposure are relatively high, than among those living at northern latitudes. Because exposure to ultraviolet light from sunlight leads to the production of vitamin $\mathrm{D}$, researchers hypothesized that variation in vitamin $\mathrm{D}$ levels might account for this association. However, additional research based on stronger study designs is required to determine whether higher vitamin $\mathrm{D}$ levels are related to lower cancer incidence or death rates. ${ }^{7,8}$

Vitamin D, traditionally known as an essential nutrient, is a precursor of a potent steroid hormone that regulates a broad spectrum of physiological processes. In addition to its classical roles in bone metabolism, epidemiological, preclinical, and cellular research during the last decades, it revealed that vitamin D may play a key role in the prevention and treatment of many extra-skeletal diseases such as cancer. Vitamin D, as a prohormone, undergoes twostep metabolism in liver and kidney to produce a biologically active metabolite, calcitriol, which binds to the vitamin D receptor (VDR) for the regulation of expression of diverse genes. In addition, recent studies have revealed that vitamin $\mathrm{D}$ can also be metabolized and activated through a CYP11A1-driven non-canonical metabolic pathway. Numerous anticancer properties of vitamin $\mathrm{D}$ have been proposed, with diverse effects on cancer development and progression. However, accumulating data suggest that the metabolism and functions of vitamin D are dysregulated in many types of cancer, conferring resistance to the antitumorigenic effects of vitamin $\mathrm{D}$ and thereby contributing to the development and progression of cancer. Thus, understanding dysregulated vitamin $\mathrm{D}$ metabolism and function in cancer will be critical for the development of promising new strategies for successful vitamin D-based cancer therapy. ${ }^{3}$

One potential caveat of systemic activation of vitamin $D$ signaling would be the high risk of hypercalcemia, which can result in serious detrimental health effects. To minimize the hypercalcemic effect, many efforts are currently being directed to develop biased agonists of VDR that have little effect on inducing hypercalcemia while retaining anticancer activities comparable to those of calcitriol. To date, nearly 1500 vitamin D analogs have been tested for such effects, but only a few among those compounds have been approved for further evaluation in clinical trials in patients with leukemia, breast, prostate, and colon cancers. Moreover, the metabolites produced from the CYP11A1-driven alternative vitamin D 
metabolism pathway have been shown to be a biased agonist of VDR with less calcemic effect while retaining anti-proliferative properties in cancer comparable to those of calcitriol. As the alternative vitamin D metabolism pathway via CYP11A1 is just beginning to be understood, its role in cancer and the relative contributions of VDR and ROR are largely unknown. Thus, intensive research on the alternative vitamin $\mathrm{D}$ metabolism pathway and successful application of this pathway for cancer therapy is warranted in the future. In addition, increasing local concentrations of calcitriol in cancer cells would be another strategy to avoid the hypercalcemic effect of calcitriol. As a calcitriol degrading enzyme, CYP24A1 is frequently overexpressed in many cancers; the inhibition of CYP24A1 can increase local concentrations of calcitriol in cancer cells ${ }^{6}$. Indeed, recent studies showed that inhibition of CYP24A1 by genetic knockdown or pharmacological inhibition greatly sensitized the anticancer effect of calcitrio.1 So far, several CYP24A1specific inhibitors have been developed for clinical purposes and it remains to be seen whether any of these will be used for cancer therapy with suitable clinical effectiveness and safety. ${ }^{4,5}$

Additionally, because the expression levels of CYP27B1, VDR, CYP11A1, and RORa/ $\gamma$ in cancer cells progressively decline during cancer progression as discussed earlier, the effectiveness of vitamin D-based therapy may be limited to only early stages, but not late stages, of cancer. Thus, identifying and developing novel diagnostic markers predicting the effectiveness of vitamin $\mathrm{D}$-based cancer therapy may be indispensable for the successful application of such a strategy. Moreover, improved understanding of the mechanisms by which cancer progression reduces the expression of those enzymes will be a critical step for successful vitamin D-based cancer therapy. Currently, as discussed above, the mechanisms that regulate the expression and/or activity of metabolic enzymes involved in CYP27B1-VDR and CYP11A1-RORa/Y pathways are poorly understood. Recent advances in understanding cancer metabolism suggest that many oncogenic signaling pathways converge on metabolic pathways by regulating the expression and/or activity of metabolic enzymes ${ }^{17-19}$. Accordingly, these oncogenic signaling pathways are highly likely to regulate the expression and/or activity of enzymes involved in vitamin D metabolism and function. Unraveling such intricate networks involving the oncogenic and vitamin D metabolism pathways will contribute to the understanding of dysregulated vitamin D metabolism and function in cancer and also provide promising new opportunities for cancer therapy.

\section{Conclusion}

This study showed the relationship between vitamin D and carcinogenesis, as well as the clinical impact of vitamin D deficiencies on cancer risk and prognosis. It was found that vitamin D plays a critical role in both direct and indirect tumor suppression mechanisms.

\section{References}

1. Prasad, K. N., Prasad, C., \& Prasad, K. N. Fighting cancer with vitamins and antioxidants. Healing Arts Press. 2011.

2. Dasgupta, A. Antioxidants in food, vitamins and supplements: Prevention and treatment of disease. Elsevier. 2016.

3. Grant, W. B. A review of the evidence supporting the vitamin D-cancer prevention hypothesis in 2017. Anticancer Research. 2018; https://doi.org/10.21873/anticanres. 123 31

4. Gnagnarella, P., Muzio, V, et al. Vitamin D supplementation and cancer mortality: Narrative review of observational studies and clinical trials. Nutrients. 2021; 13(9): 3285 .

https://doi.org/10.3390/nu13093285

5. Jeon, S.-M., \& Shin, E.-A. Exploring vitamin $\mathrm{D}$ metabolism and function in cancer. Experimental \& Molecular Medicine. 2018; 50(4): 1-14. https://doi.org/10.1038/s12276-0180038-9

6. Haschek, W. M., Rousseaux, C. G., \& Wallig, M. A. Toxicologic Pathology: An 
introduction. Haschek and Rousseaux's

Handbook of Toxicologic Pathology. 2013; 1-9. https://doi.org/10.1016/b978-0-12415759-0.00094-7

7. Bilani, N., Elson, L., Szuchan, C., Elimimian, E., Saleh, M., \& Nahleh, Z. Newly-identified pathways relating vitamin $\mathrm{D}$ to carcinogenesis: A Review. In Vivo. 2021; 35(3): 1345-1354. https: / / doi.org/10.21873/invivo. 12387

8. Hatta, M. N., Mohamad Hanif, E. A., Chin, S.-F., \& Neoh, H.-min. Pathogens and carcinogenesis: A Review. Biology. 2021; 10(6):

533. https://doi.org/10.3390/biology10060533

9. Askandar, B., Ekaputra, V. G., \& Iskandar, T. M. Comparison of VDR expression and blood vitamin D $1.25(\mathrm{OH}) 2$ level between cervical cancer patients and normal women. Indonesian Journal of Cancer. 2020; $14(3)$ : 80. https://doi.org/10.33371/ijoc.v14i3.719

10. Zhou, J., Ge, X., Fan, X., Wang, J., Miao, L., \& Hang, D. Associations of Vitamin D status with colorectal cancer risk and survival. International Journal of Cancer. 2021. 149(3); 606-614. https://doi.org/10.1002/ijc.33580

11. Marzban, M., Kalantarhormozi, M., Mahmudpour, M., Ostovar, A., Keshmiri, S., Darabi, A., khajeian, A., Bolkheir, A., Amini, A., \& Nabipour, I. Prevalence of vitamin $\mathrm{D}$ deficiency and its associated risk factors among rural population of the northern part of the Persian Gulf. 2020; https://doi.org/10.1186/s12902-02100877-5

12. Niedermaier, T., Gredner, T., Kuznia, S., Schöttker, B., Mons, U., \& Brenner, H. Vitamin D supplementation to the older adult population in Germany has the costsaving potential of preventing almost 30000 cancer deaths per year. Molecular Oncology. 2021; 15(8): 1986-1994. https://doi.org/10.1002/1878-

0261.12924

13. Kim, H., Lipsyc-Sharf, M., Zong, X., Wang, X., Hur, J., Song, M., Wang, M., SmithWarner, S. A., Fuchs, C., Ogino, S., Wu, K., Chan, A. T., Cao, Y., Ng, K., \& Giovannucci, E. L. Total vitamin $\mathrm{D}$ intake and risks of early-onset colorectal cancer and precursors. Gastroenterology. 2021; 161(4). https://doi.org/10.1053/j.gastro.2021.07. 002

14. Orkaby, A. R., Djousse, L., \& Manson, J. A. E. Vitamin D supplements and prevention of cardiovascular disease. Current Opinion in Cardiology. 2019; 34(6): 700-705. https://doi.org/10.1097/hco.0000000000 000675

15. Zhang, X., \& Niu, W. Meta-analysis of randomized controlled trials on Vitamin D supplement and cancer incidence and mortality. Bioscience Reports. 2020: 39(11). https://doi.org/10.1042/bsr20190369

16. Chandler, P. D., Chen, W. Y., Ajala, O. N., Hazra, A., Cook, N., Bubes, V., Lee, I.-M., Giovannucci, E. L., Willett, W., Buring, J. E., \& Manson, J. A. E. Effect of vitamin D3 supplements on development of Advanced Cancer. JAMA Network Open. 2020; 3(11). https://doi.org/10.1001/jamanetworkope n.2020.25850

17. Brenner, H., Kuznia, S., Laetsch, C., Niedermaier, T., \& Schöttker, B. Prevention of advanced cancer by vitamin D3 supplementation: Interaction by body mass index revisited. Nutrients. 2020; 13(5): 1408.

https://doi.org/10.3390/nu13051408

18. Aytekin, A. Comparison of vitamin D levels between healthy individuals and cancer patients. Eurasian Journal of Medical Investigation. 2020; https://doi.org/10.14744/ejmi.2020.4119 $\underline{5}$ 
19. Bandera Merchan, B., Morcillo, S., MartinNuñez, G., Tinahones, F. J., \& MaciasGonzález, M. The role of Vitamin D and VDR in carcinogenesis: Through epidemiology and basic sciences. The Journal of Steroid Biochemistry and Molecular Biology. 2017. 167; 203-218. https://doi.org/10.1016/i.jsbmb.2016.11. $\underline{020}$ 